\title{
Working Photos: Propaganda, Participation, and the Visual Production of Memory in Nazi Germany
}

\author{
Ulrich Prehn
}

ABSTRACT. This article examines images of Germany's "working world" in the 1930s and 1940s. Analyzing photos from three different genres - factory photography, special-occasion industrial photography, and the work of nonprofessional photographers - it addresses a series of questions: How was the "working world" depicted in photographs from this period? What were the different modes, functions, and effects of visual representations of work and workers in these three genres? In what ways did these photographs contribute to the (visual) production and "shaping" of memoryin terms of worker experiences, as well as with respect to attempts by the National Socialists to promote ideological notions of community-building (Vergemeinschaftung)? The main argument is that photography served as an important tool for the mobilization and self-mobilization of German workers under the Nazi regime.

Dieser Aufsatz untersucht Bilder der "Arbeitswelt" Deutschlands aus den 1930er- und 1940er-Jahren. Anhand von aus drei unterschiedlichen Genres stammenden Fotografien-Werksfotografien, zu besonderen Anlässen hergestellte Industriefotografien und Amateurfotografien-werden eine Reihe von Fragen angesprochen: Wie stellte sich die Arbeiterwelt in Fotografien aus dieser Zeit dar? Welches waren die unterschiedlichen Arten, Funktionen und Wirkungen der visuellen Repräsentation von Arbeit und Arbeitern in diesen drei Genres? Wie genau trugen diese Fotografien zur (visuellen) Produktion sowie zur Formung und "Gestaltung" von Erinnerung beiim Sinne von Arbeitererfahrungen, aber auch im Hinblick auf die Versuche der Nationalsozialisten, ideologische Vorstellungen von Vergemeinschaftung zu fördern? Wie gezeigt wird, hat Fotografie als wichtiges Werkzeug der Mobilisierung wie auch der Selbstmobilisierung deutscher Arbeiter unter dem nationalsozialistischen Regime gedient.

$\mathrm{P}$ HOTOGRAPHY is almost taken for granted today as the "key medium of the industrial age."1 Yet, photographs of industrial and workplace settings only became commonplace beginning in the interwar period. ${ }^{2}$ This article examines photographic depictions of the world of work in Germany's industrial heartland during the Nazi era. After a brief preliminary look at how the figure of the worker was stylized in Nazi propaganda photography, it focuses on the different genres of factory photography and special-occasion industrial photography, examining them through a detailed analysis of examples taken from two German companies. These are then juxtaposed with an (originally) private photo taken on company premises in order to get

Translated from the original German by Wayne Yung (Berlin) and Andrew I. Port (Detroit).

${ }^{1}$ Quote from Wolfgang Hesse in "Fotokultur-Fotowissenschaft-Fotopolitik. E-Mail-Interview von Esther Bauer und Jürg Schneider mit Wolfgang Hesse," in Blickfänger. Fotografien in Basel aus zwei Jahrhunderten, ed. Esther Bauer and Jürg Schneider (Basel: Christoph Merian Verlag, 2004), 42.

${ }^{2}$ Karl-Peter Ellerbrock claims that the 1920 s was the decade in which the working world pushed its way into the "middle of the picture." See Ellerbrock, "Im Fokus der Kamera: Menschen und Fabrikhallen. Anmerkungen zur Industriefotografie im Ruhrgebiet," in Geschichte—Unternehmen—Archive, ed. Wilfried Feldenkirchen, Susanne Hilger, and Kornelia Rennert (Essen: Klartext, 2008), 503. Reinhard Matz makes an even more specific statement, writing that "at the start of the 1930s, the workplace increasingly became a subject for photography." See Matz, Industriefotografie. Aus Firmenarchiven des Ruhrgebiets (Essen: Kulturstiftung Ruhr, 1987), 10. 
at photography's role in generating and shaping memories of the workplace This analysis addresses a central question about the visual production of memory, a basic function of photography: the way it guides the viewer, defining what should be remembered (through framing, arrangement, content, and ambiance), as well as how something — even a fleeting moment—should be remembered, whether by the direct participants, uninvolved contemporary viewers, or future audiences.

Photos from the world of work often depict not only a concrete location, but also a space for personal relationships and experiences. The working world is more than a production site and a designated environment for the workforce: it is also a place of social relationships among workers, supervisors, apprentices, trainers, craftsmen, administrative personnel, and managerial staff-interpersonal relationships over which the overarching dynamic between "capital" and "labor" casts its shadow. Even before coming to power, the National Socialists made a special effort to demonstrate publicly their respect for workers, an effort that intensified after the May 1933 destruction of the trade unions, which were then subsumed into the Nazi-controlled German Labor Front (Deutsche Arbeitsfront, or DAF), as well as after the unleashing of terror tactics against Social Democratic and Communist labor organizations and their representatives. The Nazis often summarized this labor ideal in formulaic expressions, such as those in praise of "productive hands" and the Ehre der Arbeit (Honor of Work). ${ }^{3}$ Ever mindful of the public relations impact, Robert Ley, the head of the DAF, was particularly diligent in availing himself of every opportunity to be photographed and filmed shaking hands with workers during factory visits. ${ }^{4}$

Scholars have frequently observed that Nazi propaganda tended to valorize "the worker"especially on a symbolic level, and much more the male worker than the female one. Yet, although the world of work had already become an important photographic subject in Germany well before the National Socialists came to power in 1933, there has been very little research about the degree to which Nazi worker imagery-for instance, in terms of symbolism and symbolic arrangements - continued previous traditions in the photographic representation of work, everyday life in the workplace, and workers themselves. ${ }^{5}$ This important issue goes beyond the scope of the present article, which focuses on the ways in which different photographic genres - propaganda photographs, amateur photography, as well as photos of special occasions in factories-represented and visualized the working world in Nazi Germany. The following question is just as important: to what extent-based on such visualizations-can community formation (Vergemeinschaftung), mobilization, and self-mobilization be demonstrated in photographs, as well as in the act of photography itself? Finally, and with an eye to such images, the article considers the various forms of memory and memory production with regard to these three genres.

The genre that generally dominates scholarly discussion of photographic representation under National Socialism - either as a research topic in its own right or merely as a visual adjunct for textual analysis - is propaganda photography. The first section, which focuses on this genre,

\footnotetext{
${ }^{3}$ Lüdtke, “"Ehre der Arbeit,”" 344.

${ }^{4}$ On the issue of symbolic arrangements, especially in terms of traditions, "innovations," and ideological background, see Alf Lüdtke, “"Ehre der Arbeit'. Industriearbeiter und Macht der Symbole. Zur Reichweite symbolischer Orientierungen im Nationalsozialismus," in Arbeiter im 20. Jahrhundert, ed. Klaus Tenfelde (Stuttgart: Klett-Cotta, 1991), 343-92; Rüdiger Hachtmann, "Vom 'Geist der Volksgemeinschaft durchpulst,"” Zeitgeschichte-online, Jan. 2010 (www.zeitgeschichte-online. de/zol-sprachpolitik-2010); Michael Wildt, "Der Begriff der Arbeit bei Hitler," in Arbeit im Nationalsozialismus, ed. Marc Buggeln and Michael Wildt (Munich: De Gruyter Oldenbourg, 2014), 3-24. On contemporary photographic representations of "work" and "workers," see Irene Ziehe, “'Der Steiger steht am Apparat und knipst.' Zur Darstellung von Arbeit in privaten Fotografien," in Produktion und Reproduktion. Arbeit und Fotografie, ed. Wolfgang Hesse, Claudia Schindler, and Manfred Seifert (Dresden: Thelem, 2010), 97-114.

${ }^{5}$ Lüdtke, "“Ehre der Arbeit."” Nazi invocations and proclamations of "honor" frequently praised not only the worker, but also the farmer. See, e.g., Anon., "Bauer und Arbeiter haben ihre Ehre wieder. Das deutsche Volk hat zu den wahren Werten seines Daseins zurückgefunden," in Arbeitertum 8, no.8 (1938-39): 7-9.
} 


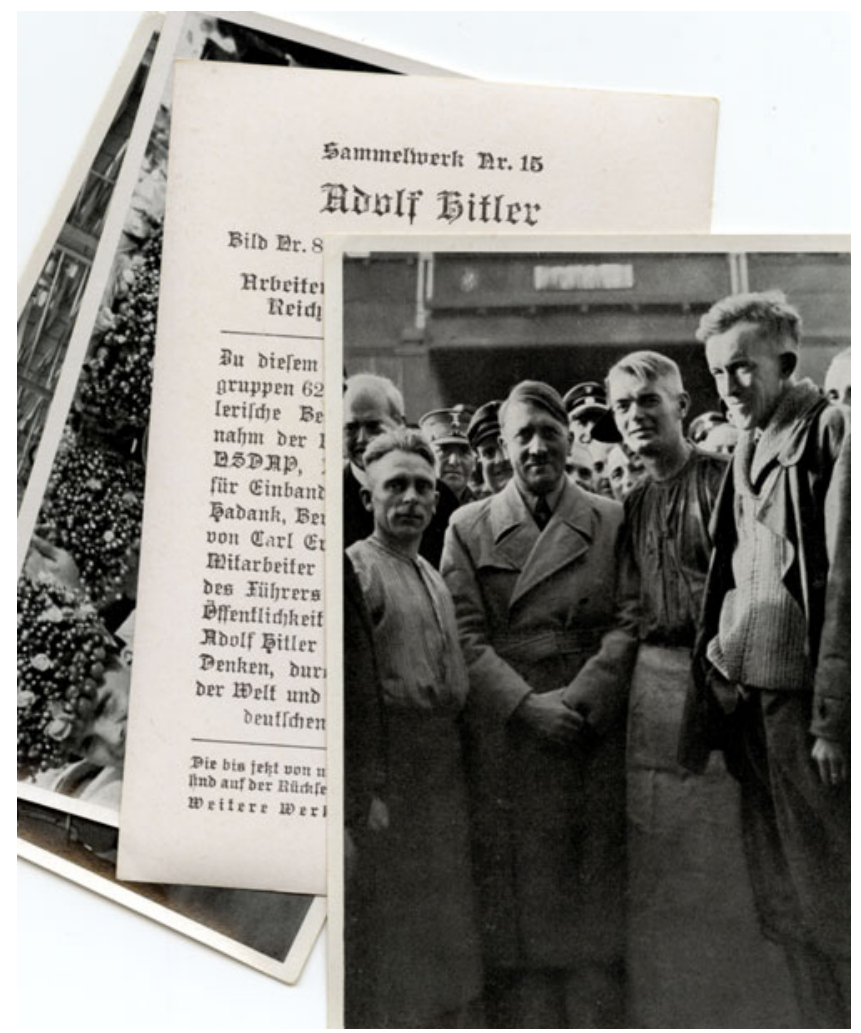

Fig. 1. (Color Online) Examples from the cigarette-card series "Collection No. 15, Adolf Hitler - Pictures from the Life of the Führer," including a photo of Adolf Hitler meeting workers in the Berlin Siemensstadt district (c. 1932). Source: Ulrich Prehn private collection, 1002.

serves as an introductory foil for an analysis later in the article of more complex and less straightforward images of the working world, including ones of company premises and workplaces themselves.

\section{Propaganda Photography and Factory Photography}

A friendly-looking Adolf Hitler in civilian clothing gazes into the camera, surrounded by three men in work uniforms; other men in uniforms or suits stand in the background (Figure 1). The image is one of two hundred collectable pictures from the 1936 mass-produced, cigarettecard series Sammelwerk Nr. 15, Adolf Hitler-Bilder aus dem Leben des Führers (Collection No. 15, Adolf Hitler: Pictures from the Life of the Führer). It is revealed on the back of the circulated print of the photo that the photographer was Heinrich Hoffmann (1885-1957), the official "photo reporter of the Nazi Party" and the person in charge of the "selection and artistic treatment of the images" for this "collection." "It is quite possible that this photo was not taken by Hoffmann

\footnotetext{
${ }^{6}$ See Eike Hennig, "Hitler-Porträts abseits des Regierungsalltags. Einer von uns und für uns?," in Führerbilder. Hitler, Mussolini, Roosevelt, Stalin in Fotografie und Film, ed. Martin Loiperdinger, Rudolf Herz, and Ulrich Pohlmann (Munich: Piper, 1995), 36-37. The highest known print-run number of this series, which was published by the CigarettenBilderdienst, Hamburg-Bahrenfeld (i.e., the Reemtsma cigarette company), indicates that there were at least 2.4 million copies. See the corresponding title entry in the online catalogue of the Eutin Regional Library: www.lb-eutin.de.
} 


\section{thiouf Giflex}

Bill I2r. 82

(6)

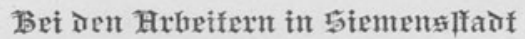

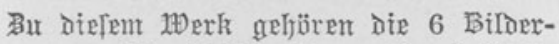
gxuppen 62-67. Die Ausmalj und künlfIerifdue Bearbeifung Dex biloxx übernalm Der Reidy- biloberidfferffaffer Der

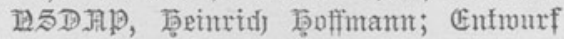

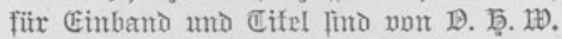

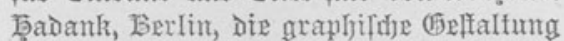

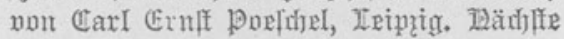
7) ifarbeifer und ältelfe Tsampfornolfen Deg Fiilfrera fpredfen in Diefem but zur

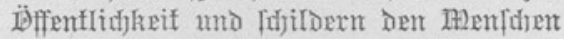
Moolf bitlex in feintem klarem Fïflen und Denken, Durdy Das ex lidf Dix Buffung

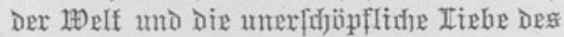
Denfluden Dolkes exworben lyat.

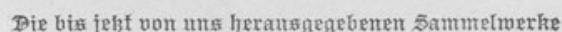

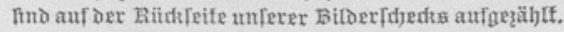

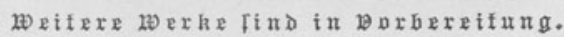

Fig. 2. Inscription on the back of a cigarette card (see Fig. 1): "Collection No. 15. Adolf Hitler. Picture No. 82. Group 64. 'With the workers at Siemensstadt.' This set includes the six picture groups 62-67. Heinrich Hoffmann, the Reich Photo Reporter of the Nazi Party, was responsible for the selection and artistic treatment... Close associates and longstanding comrades of the Führer speak out publicly in this book, describing [his] clarity of thought and feeling, which has brought him the respect of the world and the inexhaustible love of the German people." Source: Ulrich Prehn private collection, 1002 .

himself, but rather by an employee of his company Photohaus Hoffmann. ${ }^{7}$ According to the short text on the back, the image shows Hitler "with the workers at Siemensstadt" (Figure 2), a Berlin neighborhood named after the famous technology company and home to an extensive manufacturing complex, as well as worker housing estates. But the image itself conveys nothing more than what the description says ("he" with "them"). The future "Führer" stands shoulder to shoulder with "the workers" like a row of puppets in a close group arrangement, doing nothing more than looking into the camera with a collegial (if not particularly effusive) expression. Regardless of its compositional and aesthetic weaknesses, this photo, likely taken before the Nazi assumption

\footnotetext{
${ }^{7}$ According to payroll records from 1932, the company had seventeen employees, including the young Eva Braun, who worked at the shop counter. After 1933, the company "Heinrich Hoffmann, Publisher of National Socialist Pictures" grew into a major photo agency with its own press and publishing departments, eventually employing up to three hundred workers at eleven branches: its sales grew from 680,000 RM in 1933 to 15.4 million RM in 1943. See Rudolf Herz, Hoffmann \& Hitler. Fotografie als Medium des Führer-Mythos (Munich: Klinkhardt \& Biermann, 1994), 49, 52-53, 60-61.
} 
of power, was clearly meant to illustrate Hitler's alleged connection with workers by posing him "within their ranks" in an almost humble manner. ${ }^{8}$

Hitler was not the only one presented as "one of us" in Nazi propaganda aimed at workers. The producers of visual propaganda, i.e., the photo reporters themselves, were similarly stylized (by the DAF, for example) as "fellow workers with a camera." This rhetorical label was an attempt to erase the undeniable differences in terms of skill, function, and prestige between the professional photographer and the snapshot-taking worker, thereby claiming for the photo reporter a kind of "shared identity" with the depicted worker(s), bestowing upon him (or her-e.g., in the cases of Liselotte Purper, Erika Groth-Schmachtenberger, and even perhaps Ruth Hallensleben) an almost spiritual "understanding" of his photographic subject(s). ${ }^{10}$

An "understanding" of that kind was neither shared by nor asked of those photographers engaged in the much more down-to-earth business of factory photography. This genre, in fact, can be primarily understood as a form of corporate self-representation through visual means. Of all the specialized genres that photographically represent the world of work, factory photography is the most significant one, at least in terms of sheer volume. Millions of individual photos and photo series still survive in company archives, and these visual documents were usually commissioned—either from freelance or staff photographers - for a specific purpose or occasion: to document workflows and technical innovations, for example, or for the inauguration of production plants or staff canteens.

The genre of factory photography encompasses an extraordinarily broad spectrum of subjects, aesthetic approaches, and representational strategies, of course. With that in mind, the following discussion limits itself to an analysis of just two photos that are particularly suitable for illustrating the role played by still images that were meant to represent the phenomena and developments characteristic of industrial production processes found in Germany in the 1920s and 1930s. These two photos come from the venerable company Maschinenfabrik Augsburg-Nürnberg (Machine Works of Augsburg and Nuremberg, or MAN), and their main subject is the production process itself, documented by two wide shots that survey a factory floor where crankcases are being put together on an assembly line (Figures 3 and 4). ${ }^{11}$ The workers here, especially in Figure 3, seem almost like an appendage of the machinery, serving at best a symbiotic function, if not a "servile" one. Such images contrast with other common compositions of the time, which depicted "human and machine," or "worker and product," or "engineer and product": these pairs were arranged in a visual juxtaposition, mainly to give a sense of scale or to convey engineering prowess, expert workmanship, and pride in the product. ${ }^{12}$

\footnotetext{
${ }^{8}$ The image archive databank of the Preußischer Kulturbesitz ("Prussian Cultural Heritage Foundation") in Berlin dates this photo to 1932. See Bildagentur für Kunst, Kultur und Geschichte (http://www.bpk-images.de).

${ }^{9}$ See a corresponding article by Karl Hannemann, "Die Bildjäger. Arbeitskameraden mit der Kamera," in Arbeitertum 8 , no. 1 (1938-39): 20 .

${ }^{10}$ It is plausible that this "fellow-worker-with-the-camera" trope was also introduced as a Nazi substitute for an earlier (self-)understanding of the "Arbeiter-Fotograf" ("worker-photographer"), i.e., as a way of "tidying up" after the 1933 Nazi takeover and the destruction of the organized labor movement. A magazine with the same name was founded in 1926 and published by Willi Münzenberg. See Joachim Büthe et al., Der Arbeiter-Fotograf. Dokumente und Beiträge zur Arbeiterfotografie 1926-1932 (Cologne: Prometh-Verlag 1977), 34-45. In 1928, Franz Höllering, the editor-in-chief of the ArbeiterIllustrierte Zeitung, characterized the "worker-photographer" not as a "fellow worker with the camera" but rather as a "reporter and artist." See Höllering, "Der Arbeiter-Fotograf als Reporter und Künstler" (Jan. 1928), in Der Arbeiter-Fotograf. Offizielles Organ der Vereinigung der Arbeiter-Fotografen Deutschland 2, no. 5 (1927-28): 3-4.

${ }^{11}$ This use of the generic term assembly line deserves a more precise nomenclature given the existence of many highly diverse conveyor systems for assembly-line work. If one compares the conveyor seen in the MAN photos with a contemporary overview chart of the various common types in use at the time, as well as with a photographic illustration, the MAN photos seem to depict a (circulating) "Standbahntisch," i.e., a "standing-track worktable" with trays on rails for work performed while standing. See K.-H. Schmidt, "Die Fördermittel für Fließarbeit," in Fließarbeit. Beiträge zu ihrer Einführung, ed. Frank Mäckbach and Otto Kienzle (Berlin: VDI-Verlag, 1926), 95 and 103 (Fig. 103b).

${ }^{12}$ See, e.g., the photos in Matz, Industriefotografie, 74-81.
} 


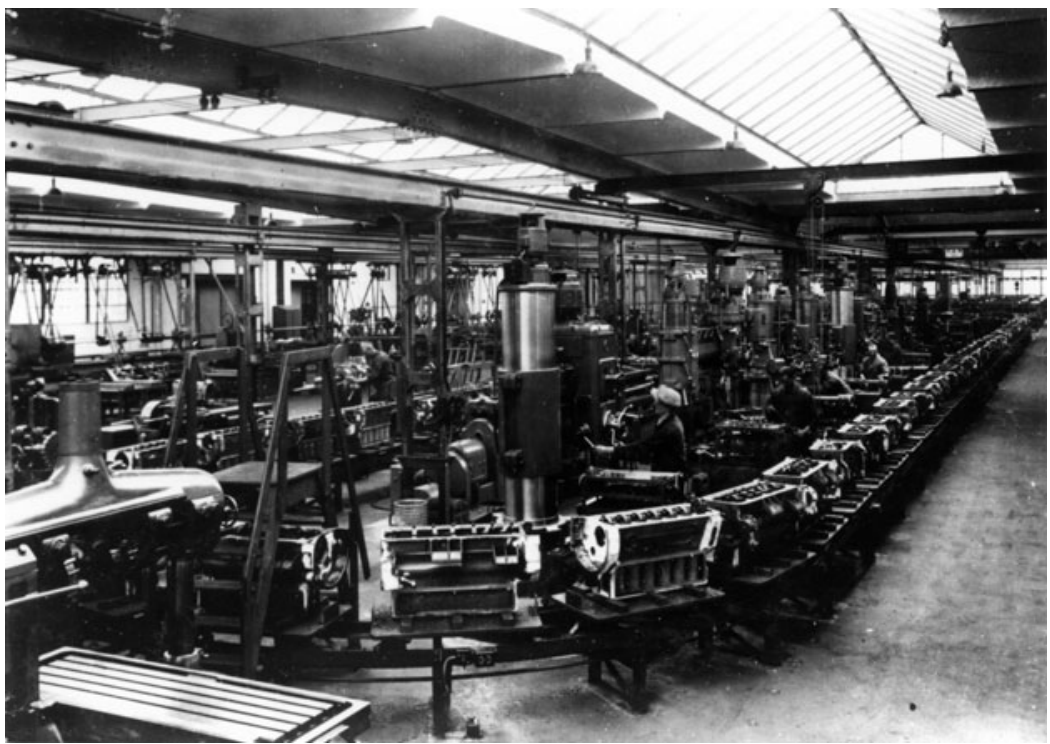

Fig. 3. Inscription on back: Workshops 1938, neg. no. 1221-9-13, wide-angle view of conveyor belt assembly of diesel engines. Source: Historisches Archiv der MAN, Augsburg.

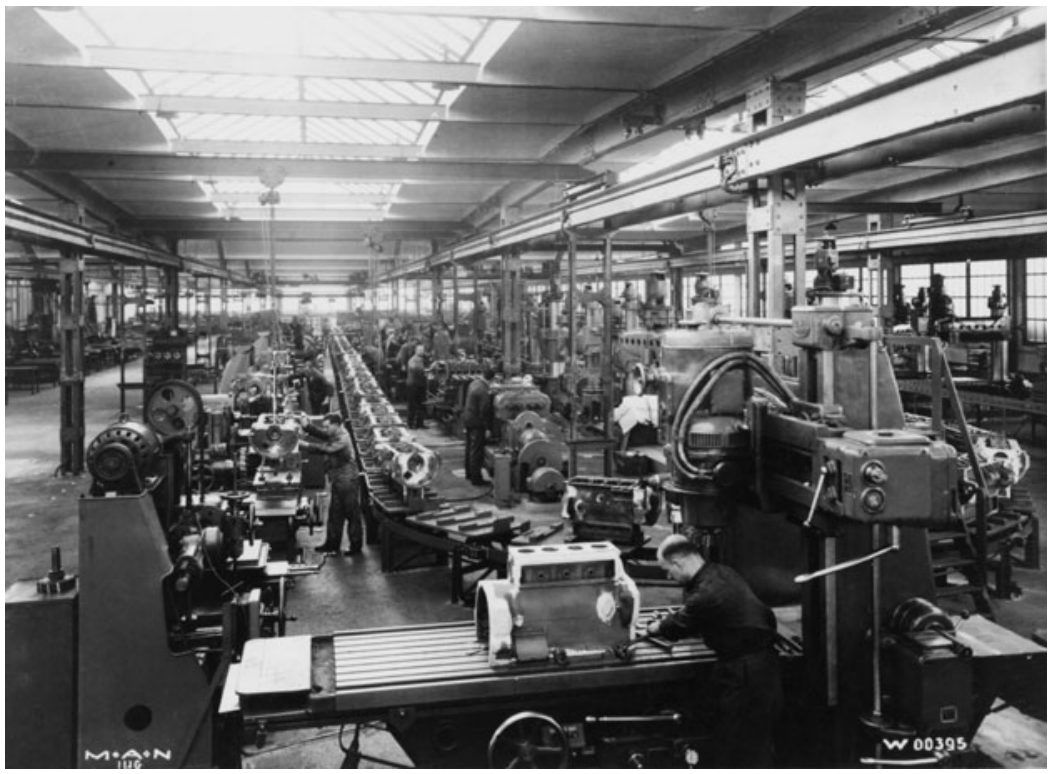

Fig. 4. Inscription on back: Factory machinery MAN 1938, neg. no. 1429-9-13, photo W 00395, industrial workstations for truck engine construction, Building E 1 A, crankcase assembly. Source: Historisches Archiv der MAN, Augsburg.

In the two MAN photos, the highly structured pictorial space is dominated by the assembly lineechoed by the bright strip of skylight—as it circulates and nearly disappears into the depths of the production hall. Yet, the assembly line seems to be at a standstill, with neither photo appearing to betray any trace of motion blur (the line may have been deliberately stopped for this photo 
shoot). ${ }^{13}$ In the "still life" in Figure 3, the workers are entirely enclosed by the assembly line. One could see them either as a vitalizing element within a coldly mechanistic framework or as an imperfect and potentially malfunctioning element within an otherwise perfect order-one that has been exhaustively calculated to the last detail in order to maximize efficiency while minimizing waste and delay in the manufacturing process. By comparison, the employees in Figure 4 seem to be somewhat more valorized, particularly the worker in the foreground, whose workstation is compositionally targeted by the axis of the assembly line as it flows in from (or out to) the distant focal point. The assembly line - as a supreme instrument ruling all work processes, and as a dominant visual element structuring the entire composition-is less emphatic in this shot than the one in Figure 3, especially since the workers here are pursuing their own individual tasks away from the assembly line.

Such attempts notwithstanding, the medium of still photography cannot adequately represent or evoke the industrial "flow" process because it can only record a single moment in space and time. Dynamic movement, a major aspect of assembly-line work, is necessarily missing from still photos. Instead, these assembly-line scenes (moments "frozen" by photography) accentuate two essential elements of operational orderliness that characterize this type of manufacturing: the sense of seamlessness and sequentiality, and the ultimate realization of ergonomically-tested industrial optimization and rationalization strategies aimed at efficiently channeling movements and manipulations, as well as physical and temporal workflows. ${ }^{14}$

Assembly-line scenes did not play any appreciable role in "official" Nazi imagery, but this is hardly surprising, since the "dehumanized" nature of assembly lines did not accommodate the Nazi rhetoric of idealized "productive hands." The DAF endeavored instead to equate assembly-line work and rationalization with its Schönheit der Arbeit (Beauty of Labor) campaign. ${ }^{15}$ It is peculiar that before the publication in 2014 of Karsten Uhl's groundbreaking study on spatial order in German industry in the twentieth century, none of the scholars who specialize in the history of rationalization or "Fordism" in Germany and North America seem to have considered the role that photography played in this context. Referring to one of the contemporary publications that included photos of assembly-line production in a German factory in the 1930s, Uhl rightly pointed out that, in the written text, those photos were explicitely classified as examples of the Schönheit der Arbeit campaign and its successes. ${ }^{16}$ Visual representations of assemblyline work may have been viewed, in a company's own visual memory, as appropriate in the 1930s for emphasizing the "appearence of modernity" in the German production and working world. ${ }^{17}$ But the use of such images for Nazi propaganda publications must have seemed not just inappropriate but also risky, for they could have potentially been interpreted as evidence of increased exploitation and alienation at the workplace. Even in contexts that might have

\footnotetext{
${ }^{13}$ Workflow stoppages for factory photography have been common practice since the early days of industrial and factory photography. See Ulrich Wengenroth, "Die Fotografie als Quelle der Arbeits- und Technikgeschichte," in Bilder von Krupp. Fotografie und Geschichte im Industriezeitalter, ed. Klaus Tenfelde (Munich: Beck, 1994), 89-105.

${ }^{14}$ See Timo Luks, Der Betrieb als Ort der Moderne. Zur Geschichte von Industriearbeit, Ordnungsdenken und Social Engineering im 20. Jahrhundert (Bielefeld: transcript, 2010), 196.

${ }^{15}$ See Josef Moser, Oberösterreichs Wirtschaft 1938 bis 1945 (Vienna: Böhlau, 1991), 297.

${ }^{16}$ Karsten Uhl, Humane Rationalisierung? Die Raumordnung der Fabrik im fordistischen Jahrhundert (Bielefeld: transcript, 2014), 61-68. Uhl refers to Karl Hilpert, Die Rundfunk-Industrie, dargestellt am Beispiel der Blaupunkt-Werke G.m.b.H. Berlin-Wilmersdorf (Leipzig: J. J. Arnd, Verlag Übersee-Post, 1939), 22-23. Studies that appeared before Uhl include, e.g., Rüdiger Hachtmann, Industriearbeit im "Dritten Reich". Untersuchungen $z u$ den Lohn- und Arbeitsbedingungen in Deutschland 1933-1945 (Göttingen: Vandenhoeck \& Ruprecht, 1989); Mary Nolan, Visions of Modernity. American Business and the Modernization of Germany (New York: Oxford University Press, 1994).

${ }^{17}$ Bernd Weisbrod, "Der Schein von Modernität. Zur Historisierung der 'Volksgemeinschaft,"” in Geschichte als Möglichkeit. Über die Chancen von Demokratie. Festschrift für Helga Grebing, ed. Karsten Rudolph and Christl Wickert (Essen: Klartext, 1995), 224-42.
} 


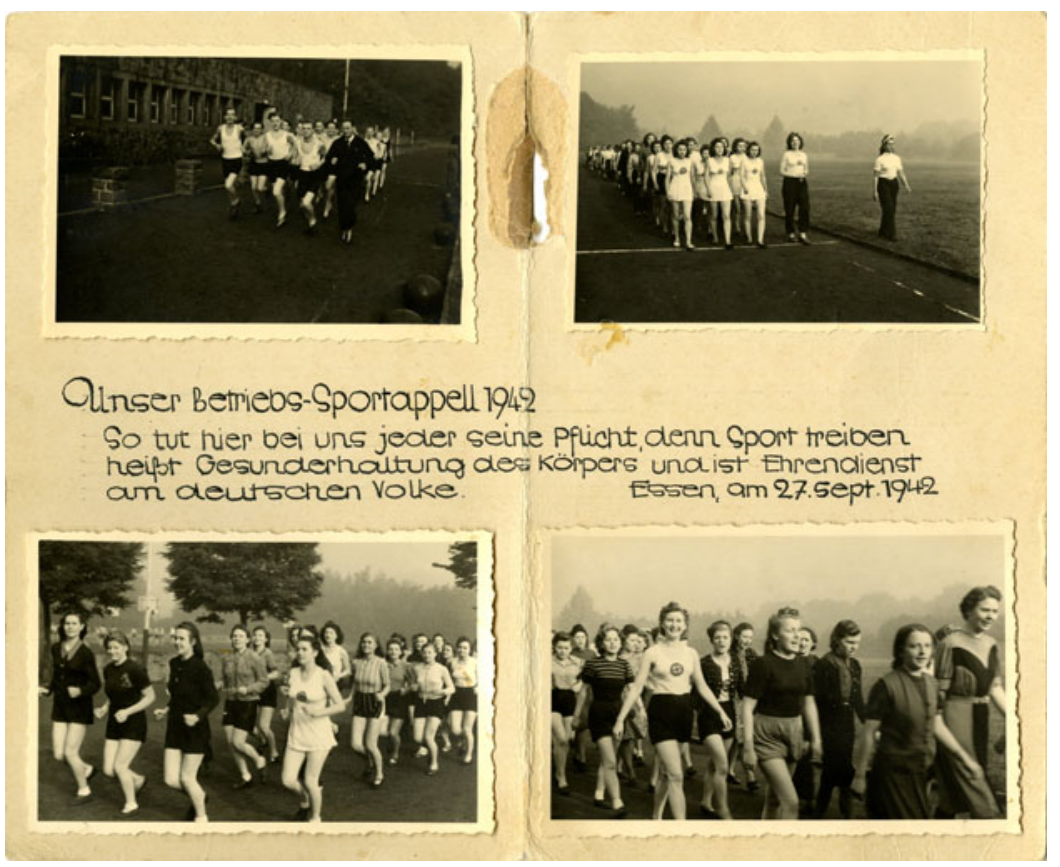

Fig. 5. (Color online) One page affixed with four photos showing employees from an unknown company: "Our company sports rally 1942. This is how every one of us does his duty. Physical exercise means keeping the body healthy, which is a service that honors the German people. Essen, Sept. 27, 1942." Source: Ulrich Prehn private collection, 436.

accommodated images of automation and rapidly flowing assembly lines - such as when visualizing the "Rhythm of Work," as in the title of an article published in Arbeitertum (Workerdom) magazine in 1936- photojournalism editors avoided photos like these from MAN showing assembly-line production, often in favor of shots depicting workers near workbenches or giant flywheels. ${ }^{18}$

Long before the National Socialists came to power, the genre of workplace photography had been dominated by certain themes and subjects, such as production processes, finished products, producers as members of a collective (i.e., with specific roles in the workforce), as well as "man and machine." But any photographic documentation of production processes and technical standards ultimately had to serve the practical needs of the company. What could be read as an infusion of National Socialist ideology into the genre of workplace photography turned instead to areas that often had little direct relevance to the workplace as a site of production, such as company sports events (Figure 5), celebrations, and roll calls (Figure 6). ${ }^{19}$ Similar subjects included "National

\footnotetext{
${ }^{18}$ See J.B.R. (aka J.B. Ring), “Rhythmus der Arbeit. Im Takt unserer großen Zeit,” in Arbeitertum 6 , no. 1 (1936-37): $24-26$.

${ }^{19}$ A photo from a company roll call at the Allgemeine Elektricitäts-Gesellschaft (AEG) in Berlin, likely commissioned in 1935 by the Nazi factory cell of the AEG, was published in the magazine Arbeitertum with a caption underlining its function in promoting togetherness: "The company roll call is an expression of the solidarity between company leaders and followers." See Curt Gusko, "Vom Unternehmer zum Betriebsführer. Die Menschen sind das wertvollste Gut, nicht die Maschinen," in Arbeitertum 5, no. 1 (1935-36): 19.
} 


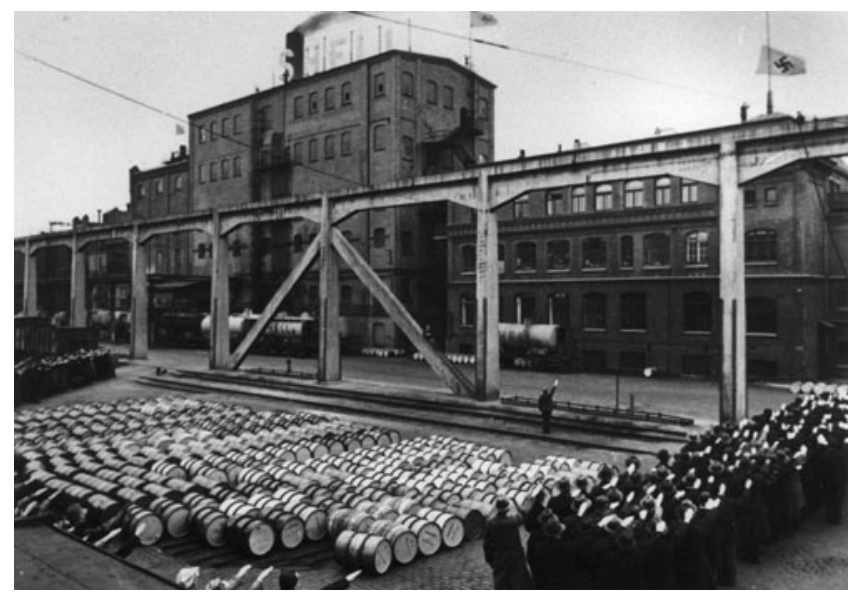

Fig. 6. Workers at the Shell plant in Grasbrook (Hamburg), assembled in a U-shaped formation around a stockpile of barrels in the yard. One man (possibly the "company leader" [Betriebsführer]) stands in front, while another stands on the roof to face the Nazi flag. They, along with the entire workforce, offer the Hitler salute to the flag, thereby demonstrating both hierarchy and togetherness. Source: Geschichtswerkstatt Wilhelmsburg \& Hafen, Hamburg.

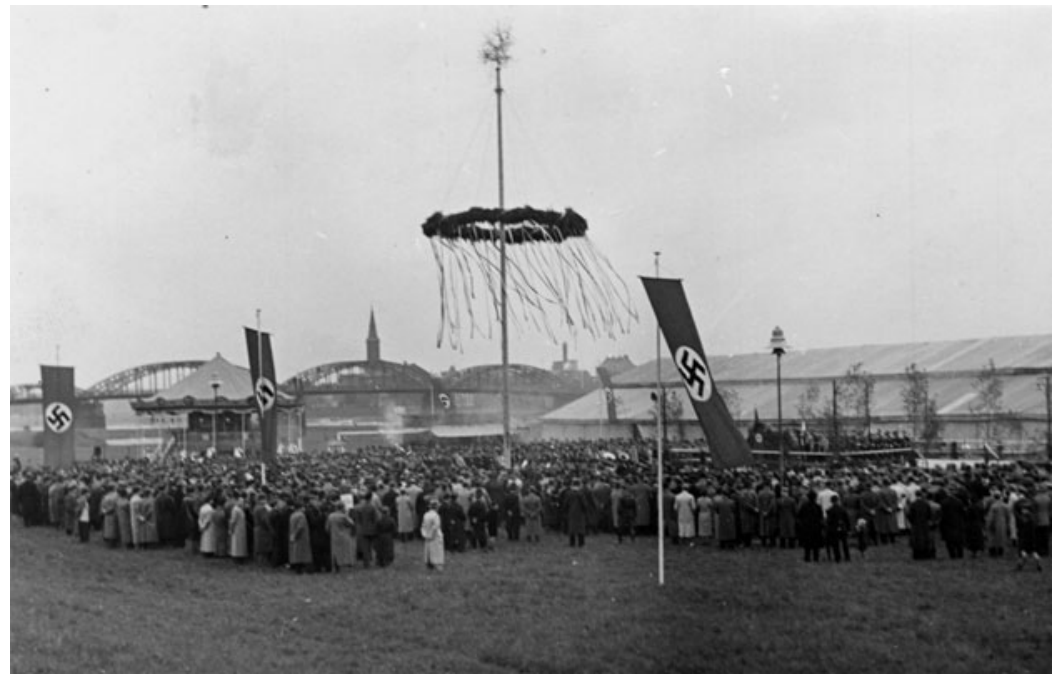

Fig. 7. On May 1, 1939, the workforce of the MAN plant in Gustavsburg gathers around a maypole, a traditional centerpiece, supplemented by three Nazi banners that help accentuate the event's dimensions and spatial depth. The Maypole ribbons and Nazi banners flutter in the breeze, adding an aesthetically pleasing accent to an otherwise unspectacular and static scene. Source: Ulrich Prehn private collection, 112b.

Vocational Competitions," the activities of the Schönheit der Arbeit campaign, and the celebration of May Day as the "Day of National Labor" (Figure 7). ${ }^{20}$ Beauty of Labor was the name of

${ }^{20}$ Reich Youth Leader Baldur von Schirach called the 1935 National Vocational Competition a "symbol of youth that perfectly embodies its grand ethos, the 'Honor of Work."' He also borrowed from the militant rhetoric of the socialist workers' movement: "Furthermore, I see in this the greatest socialist action of all times, the perennial battle cry of the productive against the exploiters. One day we will be victorious..." See the preface by Baldur von Schirach (dated April 29, 1935 in Saarbrücken), in Arbeitertum 5, no. 4 (1935-36): 3. The slogan of the 1936 National Vocational Competition later conveyed an entirely different, explicitly anti-Bolshevik sentiment: "Against Stakhanov: For the Four-Year Plan." See Kurt 
the organization founded in November 1933 under the auspices of Kraft durch Freude (Strength through Joy, or KdF), a division of the DAF charged with "developing" - i.e., organizing and permeating - the leisure activities of the German population. ${ }^{21}$

These types of extracurricular activities, as well as events that mediated between everyday work, on the one hand, and "improvement efforts" or staged festivities, on the other, were initiated by company management in coordination with the local National Socialist Factory Cell Organization (Nationalsozialistische Betriebszellenorganisation, or NSBO) and/or the DAF. Such events were frequently also the subject of the major genre of work-related photography discussed in the next section, namely the "special-occasion industrial photo."

\section{Special-Occasion Photographs}

Compared to the countless photographs of the production process made by mostly unknown factory photographers, images taken on special occasions had a much more individual touch. In addition - and as a result of the special occasion itself - the commissioned photographer apparently felt a heightened motivation to find an appropriate visual language — one that frequently aimed at an elevated manner of representation. This consequently led on such occasions, as we shall see, to photographs that may have contained subtle political and ideological messages, but that, at the same time, fully presented "ideal types" in a way desired by management. Photographers found that personal images - including ones that showed people directly at their workspace-were especially well-suited to that goal.

One can see many examples of such workplace events in the images produced by Alfred Tritschler, a prominent industrial and advertising photographer who specialized in "images of the working world." In 1937, his agency, the renowned Wolff \& Tritschler of Frankfurt am Main, was commissioned by the Mechanische Baumwoll-Spinnerei und Weberei Augsburg (Mechanical Cotton Spinning and Weaving Company of Augsburg, or SWA) to record not only the celebrations marking its hundredth anniversary, but also scenes of everyday work at the company. The latter were captured in a series of photographic "documents"-in actuality, a series of staged visual tableaux. ${ }^{22}$

Standing in front of a spinning machine, a broadly smiling, neatly dressed female worker poses for Tritschler's camera, skillfully balancing several giant spools of thread on her practiced arm (Figure 8). In contrast to her cheerful expression, however, she seems oddly hedged in by two

Eichelberger, "Der 4. Reichsberufswettkampf beginnt: 90 Prozent aller Jugendlichen haben sich gemeldet," in Arbeitertum 6 , no. 21 (1936-37): 14.

${ }^{21}$ On the "Beauty of Labor" organization and its campaigns, see Chup Friemert, Produktionsästhetik im Faschismus. Das Amt "Schönheit der Arbeit" von 1933-1939 (Munich: Damnitz, 1980); also see Anson Rabinbach, "Die Ästhetik der Produktion im Dritten Reich," in Kunst und Kultur im deutschen Faschismus, ed. Ralf Schnell (Stuttgart: Metzler, 1978), 57-85.

${ }^{22}$ After Alfred Tritschler (1905-70) submitted his resume to the renowned Frankfurt photographer Paul Wolff (1887-1951), the two men founded the "Dr. Paul Wolff \& Tritschler" photo agency in 1927. Their photo assignments included the 1936 Berlin Summer Olympics; they also offered training courses for photojournalists from 1935 to 1942. In the late 1930s, the company had around twenty employees. See the historical account on the company's website: http://drwolffundtritschler.de.tl/Bildarchiv.htm; also see Rolf Sachsse, Die Erziehung zum Wegsehen. Fotografie im NSStaat (Dresden: Philo, 2003), 436. Wolff's small-format photos of the Opel plant in Rüsselsheim, taken in 1936 with a Leica camera, helped set a new trend in factory photography. See Dr. Paul Wolff-Pionier der Kleinbildfotografie. Fotografien 1927-1939. Eine Ausstellung der Adam Opel AG, 2nd ed. (Rüsselsheim: Adam Opel, 1989), 12. Although the official company records of Opel AG do not refer to Tritschler's photos, but rather to small-format ones by Paul Wolff taken in the mid-1930s, they support the assertion that the company staged visual tableaux. Wolff relied "on taking multiple shots with small-format photos, forgoing the custom of the arranged single shot." See Ibid., 13. Surviving negatives of the photos taken by Tritschler and his staff at SWA show both methods: rapid-fire photo sequences of the same subject, as well as more meticulous arrangements and staged poses. 


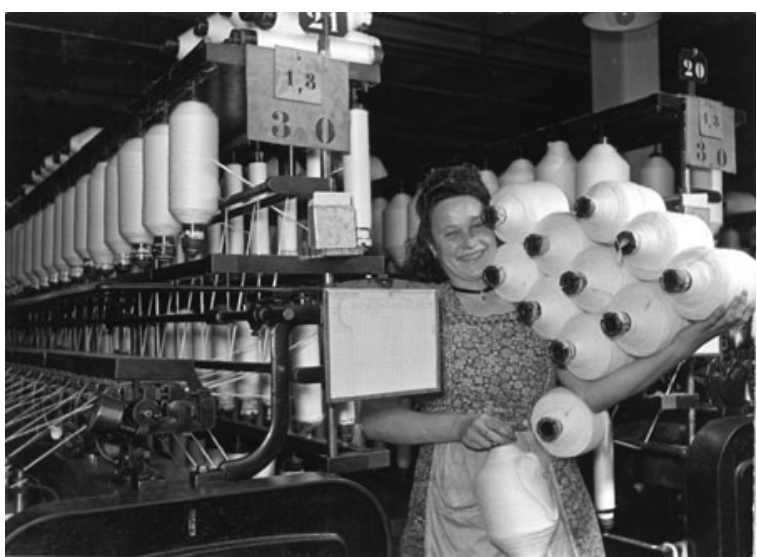

Fig. 8. Worker with spools at the Mechanical Cotton Spinning and Weaving Company of Augsburg (SWA), 1937. Photographer: Alfred Tritschler. Source: Stadtarchiv Augsburg, Fotosammlungen, SWA, No. 2049.

spinning machines, by a white sign attached to the left machine and a load of giant spools propped against her body. Her beaming expression does not accord with her physical exertion. Taken alone, the surfeit of spools (not only on her arm, but also arrayed on the spinning machines) threatens to overwhelm the crowded composition. But the image's overriding message remains clear: this is a happy (or at least contented) worker. ${ }^{23}$ The visual language Tritschler used in the scene in Figure 8, which was no doubt staged, stands in stark contrast to the credo formulated by the renowned Bauhaus architect and photographer Andreas Feininger in Menschen vor der Kamera, a "textbook of modern portrait photography" published in 1934. The section on "the "working world' in images" describes how the "productive... person was to be depicted in photos both clearly and simply": the worker should be "seen doing the work and not standing beside it ... shot in the midst of activity, and not (for example) leaning on a shovel while affably grinning at the camera!" 24

Tritschler produced other photos that conformed more closely to Feininger's recommendations, ones that presented an ostensibly more naturalistic vision of work inside the weaving factory. One pair of photos, for example, portrays tasks in the raw materials depot. The first image shows two female workers nearly buried in a mountain of raw white cotton (Figure 9). Its aesthetic qualities would have likely appealed to Tritschler because of its contrasts between humans and materials, hard edges and soft forms, whiteness and blackness, as well as the wash of light in an otherwise dark room. ${ }^{25}$ The next photo shows three male workers stacking bales of raw cotton with a hoist (Figure 10). Unlike the first image, this one, exposing grubbylooking work in a disorderly and uninviting storeroom, would hardly have been suitable for inclusion in the SWA's 1937 hundredth-anniversary commemorative volume. ${ }^{26}$ Photos like this suggest that, even when on assignment, industrial photographers sometimes took pictures inspired

\footnotetext{
${ }^{23}$ Another photo of this beaming worker also exists: a close-up shot from below, where she seems to stagger almost backwards under the weight of the spools. See Stadtarchiv Augsburg (hereafter StadtAA), photo collection, SWA 2050.

${ }^{24}$ See Andreas Feininger, Menschen vor der Kamera. Ein Lehrbuch moderner Bildnisfotografie (Halle: Heering, 1934), 66. Emphasis in original.

${ }^{25} \mathrm{~A}$ similar photo showing just one female worker amid the raw cotton was ultimately selected for the photo section of the commemorative volume. Its caption simply reads: "Im Baumwollstock" (in the cotton stockpile). See Hundert Jahre Mech. Baumwoll-Spinnerei und Weberei Augsburg (Munich: Bruckmann, 1937), unpag. photo section.

${ }^{26}$ Some 4,500 copies were printed. See the 1937 Annual Report by management in StadtAA, SWA, company files, 211,5 .
} 


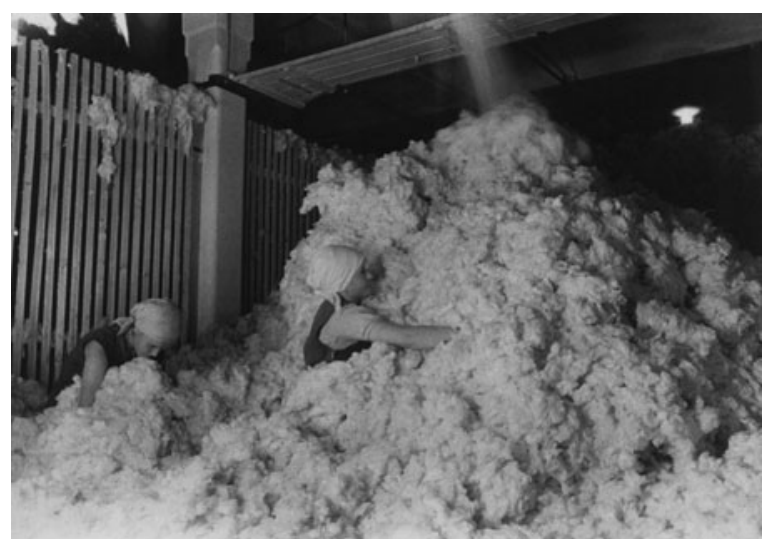

Fig. 9. Workers with raw materials at the SWA, 1937. Photographer: Alfred Tritschler. Source: Stadtarchiv Augsburg, Fotosammlungen, SWA, No. 2120.

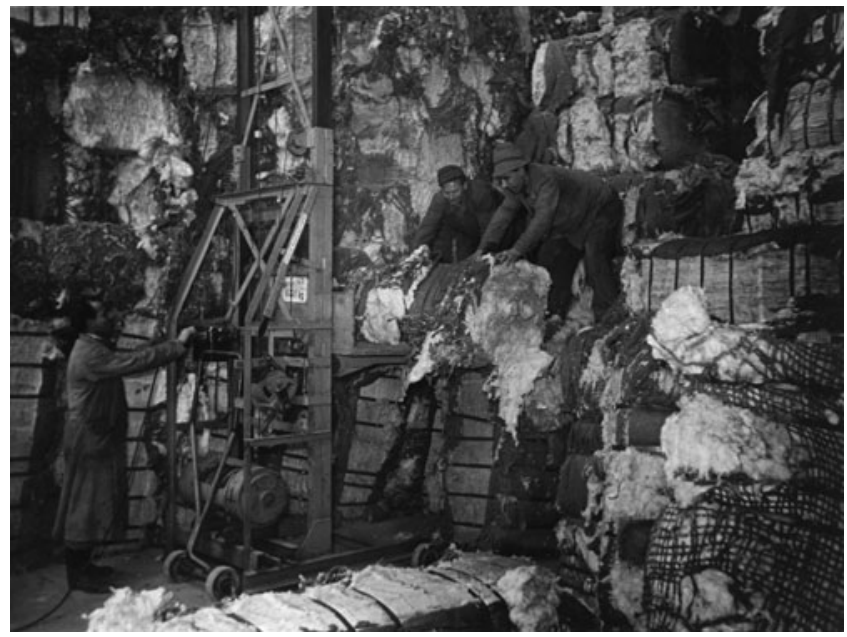

Fig. 10. Raw cotton storage depot at the SWA, 1937. Photographer: Alfred Tritschler. Source: Stadtarchiv Augsburg, Fotosammlungen, SWA, No. 2111.

by pure aesthetic interest, even though such images might not satisfy the needs of the clientnamely, the production of presentable photos for publicity purposes.

Compared to a factory's regularly employed in-house photographer, special-occasion photographers from renowned agencies like Wolff \& Tritschler enjoyed a greater degree of creative freedom. In either case, however, the client always had the final say over which photo best communicated the company's desired message. This held true even if the intended publicity goals (which dictated the choice of photographic subjects) differed for each publication format: the product catalogue, the advertising brochure, the company newsletter or-of particular importance to the SWA- a commemorative volume to mark a company anniversary.

Tritschler's visual conceptualization of workplace life at the SWA clearly suggests that he favored individual portraits over group shots. In the nineteenth and early twentieth centuries, factory photographers still tended to arrange group portraits of each department in a company, 


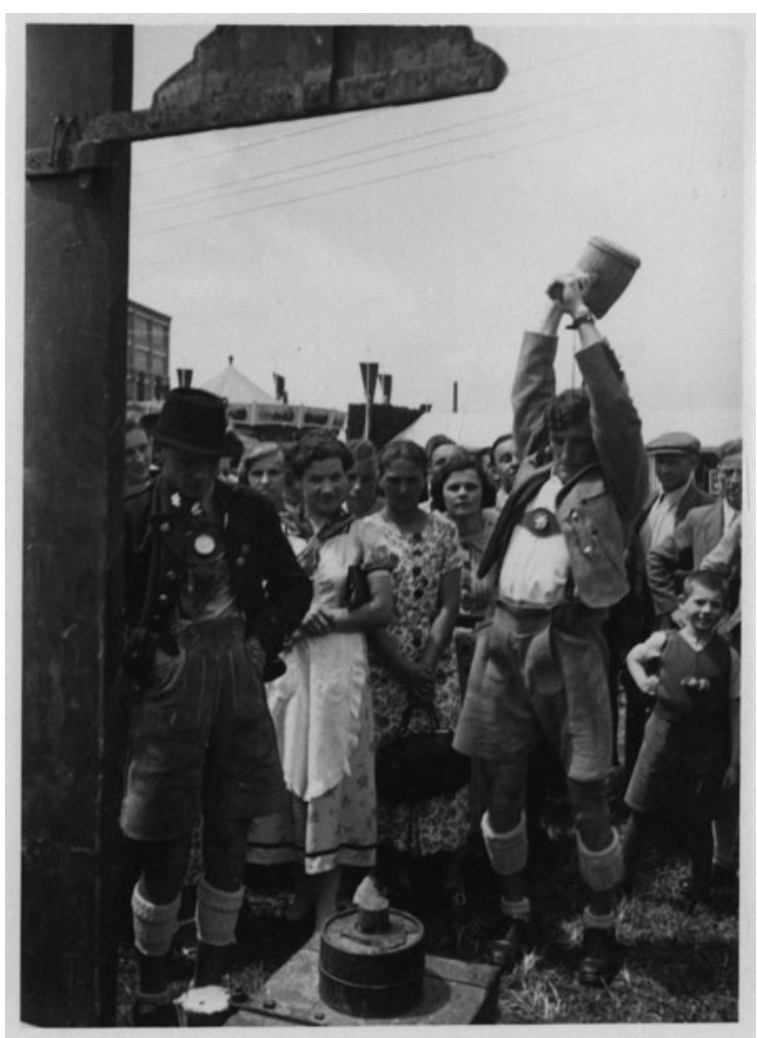

Fig. 11. Amusements at a SWA anniversary celebration in June 1937. Photographer: Alfred Tritschler. Source: Stadtarchiv Augsburg, Fotosammlungen, SWA, No. 1951.

showing the personnel of that department in rows (whether standing or sitting) while displaying their characteristic hallmarks (e.g., work clothing, products and components, raw materials, specialist tools). ${ }^{27}$ By contrast, Tritschler would frame individual workers (occasionally office clerks as well) as pars pro toto, i.e., as typical representatives of their department or of their particular function and duty in the company workflow.

In addition to the photos destined for the commemorative volume, Tritschler also took many photos of the company's anniversary festivities, as well as of the preparations for those festivities. It was in these that this master of the conventional individual portrait expanded his scope with photos that served to visualize community in at least two important ways. First, Tritschler foregrounded the community-building event itself as a photographic subject. The celebrations offered something for all of the attendees, who were largely dressed in traditional costume; this included crowd-pleasing festival attractions and fairground amusements held outdoors — such as "strongman" games (Figure 11) — as well as ceremonial speeches and stage shows for the entertainment of the

${ }^{27}$ See, e.g., Karl-Peter Ellerbrock, ed., Profile. Typen der Arbeitswelt in der historischen Werksfotografie (Essen: Krupp, 1994), 24-25; idem, "Im Fokus der Kamera," 497; Matthias Frotscher, Arbeitswelt und Alltag. Der Werkfotobestand des Kunstgussmuseums Lauchhammer (Dresden: Verlag der Kunst, 2003), 38, 59. Anton von Rieppel, General Director of the MAN company, commissioned in 1890-91 one of the most comprehensive photographic records of a company workforce. The corresponding negatives of the "Rieppel Album" are stored (noncontiguously) in the historical archive of the MAN company in boxes containing negatives numbered 31-1010, 1011-1676, and 1677-2095. 


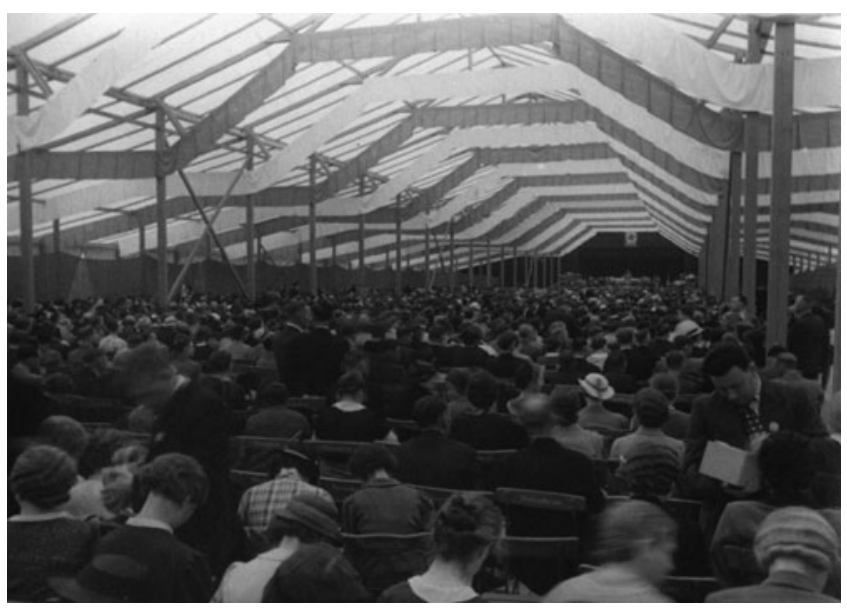

Fig. 12. Festival tent at a SWA anniversary celebration in June 1937. Photographer: Alfred Tritschler. Source: Stadtarchiv Augsburg, Fotosammlungen, SWA, No. 1973.

many guests who had gathered under the festival tent (Figure 12). ${ }^{28}$ Second, Tritschler enacted community-building — an act that was repeated with each subsequent viewing of the photo- through moments that were staged especially for the camera, such as in the photographic scene in Figure 13. Five young men-all smiling except for one-are crowding into the scene in the background, apparently to see better the presentation of a gift, a box of pralines, to a seated female worker who seems pleased to receive them. ${ }^{29}$ The friendly huddle heightens considerably the significance of this entirely unspectacular act of gift-giving by putting the photographic emphasis on "taking part" and well-wishing spectatorship. The warmth Tritschler coaxed from this scene certainly does not mean that this photo and others like it were not specifically staged for the camera-or that the participants were not at least playing along with the photographer. Indeed, the very presence of the photographer (along with any assistants) may very well have had an effect on the affect and behavior of the subjects. This can be seen, for example, in Figure 11, in which at least two of the female spectators look directly into the camera. ${ }^{30}$

According to National Socialist propaganda, the Mensch was supposed to be the "focal point" (Mittelpunkt) of the factory and of what transpired there. ${ }^{31}$ In accordance with that precept, individualization-even when it merely involved giving face to workers in a pars-pro-toto fashion-turned out to be the dominant form of photographic representation, which, in the Third Reich, was supposed to convey the importance of the human factor at the workplace.

\footnotetext{
${ }^{28}$ According to a retrospective report by SWA management, a large festival tent "on a field near our plant in Aumühle" served as an "assembly space for our guests and company personnel—about 5,000 people." See the 1937 Annual Report 1937 by management in StadtAA, SWA, company files, 211,5.

${ }^{29}$ The company bought more than just a few praline boxes for this anniversary, of course: "The monies expended for the celebration, for bonus payments to the workforce, and for various donations benefitting public causes, came to a total of about 376,000 RM." See Ibid.

${ }^{30}$ See StadtAA, SWA, company files, 189,5, invoice from the agency "Dr. Paul Wolff \& Tritschler—Photo Studios . Film Shoots - to the Mechanical Cotton Spinning and Weaving Company," June 21, 1937. The agency charged "for the preparation of a photo report of your anniversary celebration," including "transportation costs for two gentlemen," who spent three days in Augsburg in order to document the preparation and execution of the festivities.

${ }^{31}$ This was how the DAF functionary Theo Hupfauer formulated it in October 1939; quoted in Tilla Siegel, "Rationalisierung statt Klassenkampf. Zur Rolle der Deutschen Arbeitsfront in der nationalsozialistischen Ordnung der Arbeit," in Herrschaftsalltag im Dritten Reich. Studien und Texte, ed. Hans Mommsen and Susanne Willems (Düsseldorf: Schwann im Patmos Verlag, 1988), 208.
} 


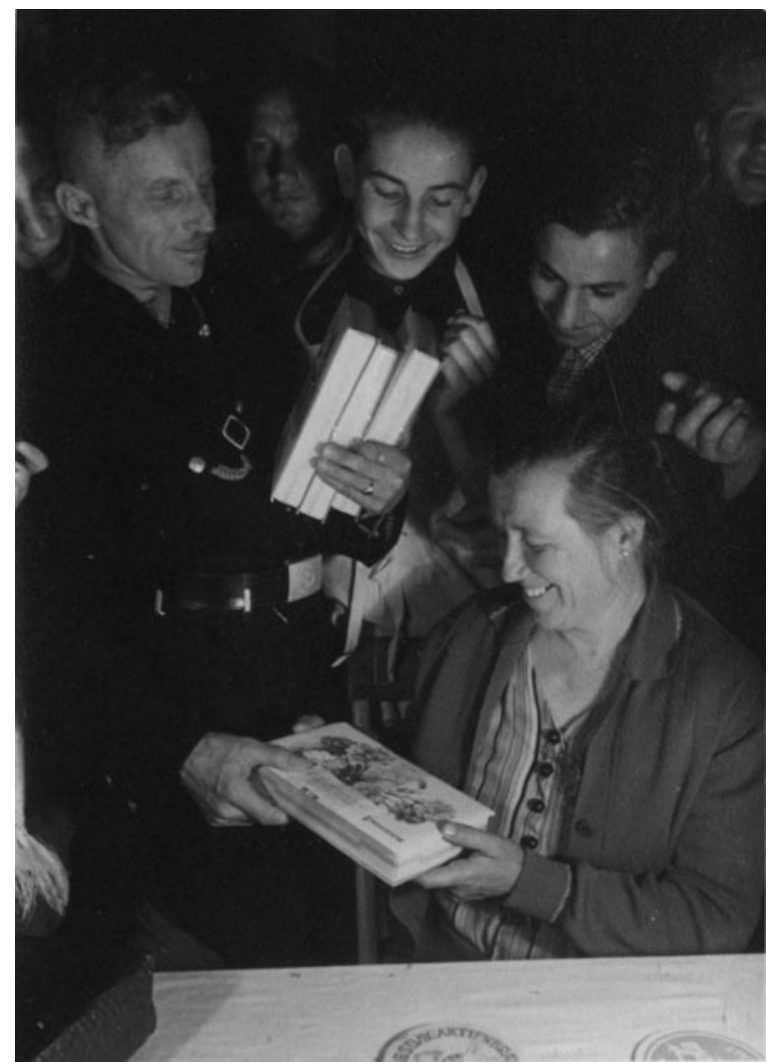

Fig. 13. Presents for SWA staff members, June 1937. Photographer: Alfred Tritschler. Source: Stadtarchiv Augsburg, Fotosammlungen, SWA, No. 1928.

\section{Grassroots Agency?}

The photo in Figure 14 handles both the topic of "work" as a photographic subject and the actual workplace as a concrete location much differently from the way in which Tritschler's photographs did. Originally in private hands (and now held by the historical archives of the MAN company in a file labeled "leisure-time activities"), this photo was clearly not the work of a professional photographer but of an amateur. One must remember that in Nazi Germany's evolving system of industrial relations, ordinary workers became increasingly integrated and "involved" in the political system. Although this development was certainly motivated and encouraged from above, it was also facilitated and reinforced by an astounding degree of dedication on the part of the employees themselves.

Figure 14, as a photographic representation of work combined with leisure on the company premises, highlights the interrelationship between prescribed goals and individual initiatives, as well as the opportunities for grassroots agency. A former MAN employee, H. K., sent this photo to the company in 1982, suggesting that it might be useful for documentation or publication purposes. ${ }^{32}$ A handwritten annotation on the back of the photo (Figure 15) reads:

\footnotetext{
${ }^{32}$ See the historical archive of the MAN company, Augsburg, 2.2.3/19, letter from engineer H. K. (of Ratingen) to MAN (Augsburg), May 3, 1982.
} 


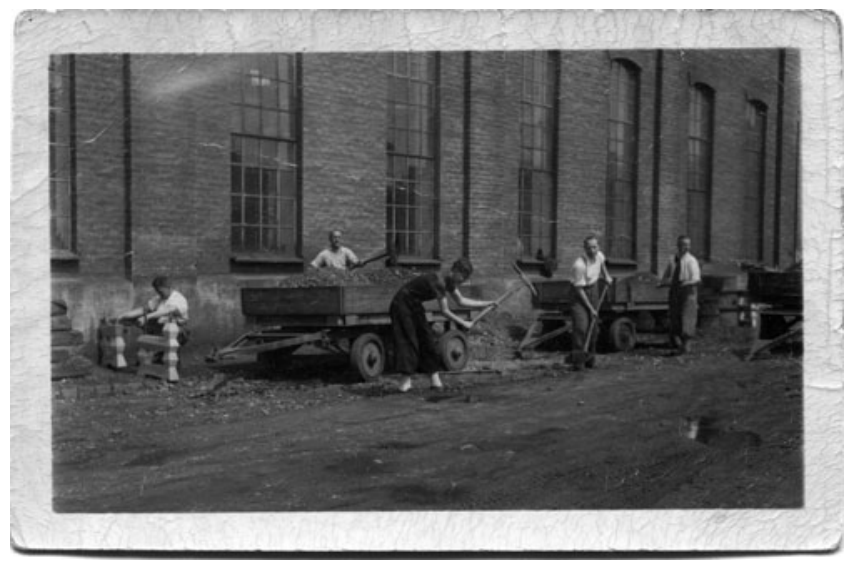

Fig. 14. After-hours volunteer work to build an employee rest area at MAN, Augsburg. Private photo, 1935. Source: Historisches Archiv der MAN, Augsburg, file group 2.2.3/19.

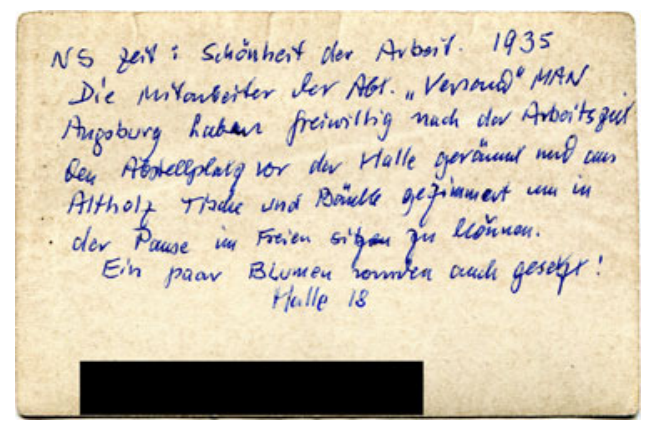

Fig. 15. (Color online) Inscription on the back side of H. K.'s photo. Source: Historisches Archiv der MAN, Augsburg, file group 2.2.3/19.

Nazi period: "Beauty of Labor," 1935.

Employees from the shipping department of MAN in Augsburg worked voluntarily after hours to clear the storage space in front of the hall, using old wood to build tables and benches so that they could sit outside during breaks.

A few flowers were also planted!

Hall 18

Proposed by K[.] $]^{33}$

Initiatives by the Beauty of Labor organization prompted companies to establish their own canteens, break rooms, and libraries, build sanitary facilities and sports facilities, as well as organize company social and sporting events and tournaments. By the end of 1935 the DAF proudly claimed to have already spent some 200 million Reichsmarks "solely for implementing 'Beauty

\footnotetext{
${ }^{33}$ The strong textual similarities between H. K.'s letter and the photo's inscription (especially the emphasis on the personal initiative of the workers at the MAN shipping department) point to the fact that the inscription was retrospectively added to the photo in 1982 (an assessment further confirmed by the use of ballpoint pen and the post-Nazi expression "NS Zeit," meaning "Nazi period").
} 
of Labor' programs in the Reich." 34 In a letter H. K. sent to MAN along with the photo, he explained the meaning of the inscription he "proposed":

Back then, I advanced the idea that we build a courtyard, using our own volunteer efforts after hours in order to create a seating area for break times. The carpenters constructed the footings for the benches and chairs (left side of the picture) using their own design. Everything was painted yellow and brown and served several years for breakfasts and lunches, while also providing pleasant breaks. Flowerbeds were installed and cultivated by the workers themselves. ${ }^{35}$

It is unclear from just the photo itself what these men are working on-until one reads the details on the back. The image itself is unimpressive, poorly composed, and hardly suited for any propaganda purposes; it simply captures an early stage of the project, showing a construction site on raw soil-but also a group of workers who have taken it upon themselves to "beautify" their breaktime arrangements. It was likely taken by an amateur, perhaps even by one of the men working on the project. The main impression it conveys is nevertheless that an "improvement" or "beautification" project has just begun. This focus on a seemingly unspectacular beginning-on the conjuring of "something from nothing"-reinforces the general sense that grassroots agency was at work. It is difficult to say whether, or to what extent, this initiative was indicative of the type of organized sociopolitical activity encouraged by the Nazis. But there are more examples from other companies as well, strongly indicating that workers willingly participated in these activities, especially when they benefited themselves from improvements such as new green spaces on the company grounds. ${ }^{36} \mathrm{H}$. K.'s photograph arguably contains a greater variety of information than most other (written) documents do. Even without the inscription on the back, the image tells us something important about those involved-for example, that these are not blue-collar but rather white-collar workers. In addition, it suggests that the colleagues in this department had not just taken an initiative to "beautify" their workspace: it was equally important to them to capture this action-getting their hands dirty together for the good of the group-on film and thus create a a tangible specimen, a print, of this communal memory.

\section{Workers' Photo Clubs}

No sources indicate whether workers' photography clubs existed at MAN, but such organizations were indeed active during this period in many workplaces. Beginning in 1936, the KdF put increasing emphasis on promoting amateur photographer training, offering six-week courses especially for this purpose; according to a contemporary article in the magazine Arbeitertum, the goal of these courses (which were directed at workers, though not at workplace photography in particular) was "for our working comrades not only to familiarize themselves with the technical aspects of photography, but also to learn how to 'see' correctly ... Participation is open to every

\footnotetext{
${ }^{34} \mathrm{~A}$ photo depicting a sports field under construction-likely on the company premises of Knorr-Bremse ("Knorr Brakes")—was published alongside an article by "R" (the initial of an unknown author) in "An der Geburtsstätte der NSBO. Die Deutsche Arbeitsfront in den Betrieben. Besuch bei der 'Knorr-Bremse," in Arbeitertum 5 no. 1 (1935-36): 11-13. For the DAF quote, see Adalbert Forstreuther, "Tat und Planung im Amt 'Schönheit der Arbeit'. Weit über 200 Millionen Mark aufgewendet," in Arbeitertum 5, no. 20 (1935-36): 11.

${ }^{35}$ See the document cited in note 33 .

${ }^{36}$ Rudolf Käs offers such an example based on an interview the Centrum Industriekultur of Nuremberg conducted with a former employee of a large company located in that city; see his "Arbeiter unterm Hakenkreuz. Zur Lage in den Großbetrieben,” in Unterm Hakenkreuz. Alltag in Nürnberg 1933-1945, ed. Centrum Industriekultur (Munich: Hugendubel, 1993), 77.
} 
Volksgenosse, even if he is not yet a member of the 'Strength through Joy' National Socialist Association." 37

Scholars have conducted little research about the types of organized activity offered to amateur photographers under the Nazi regime beyond such KdF courses, or about the extent to which such activities were absorbed or "incorporated" into already existing independent, self-initiated organizations. Evidence in various articles and notices in German amateur photography magazines suggests, however, that there was indeed significant photographic activity at the workplace and at the grassroots. The magazine Photographie für Alle (Photography for All), for example, published an article in early 1937 calling on readers to establish "workplace photography groups." The author declared that amateur photography was "no longer the prerogative of the wealthy few, having long since become a Volkssport ["pastime of the people"]," while emphasizing that the workplace photography groups he was proposing would not be in competition with regular photography clubs. ${ }^{38}$ This development seems to have already been in full swing by this time, for it was only a few months later that the same magazine not only published a change of address for the Photo Workgroup of the prominent Berlin-based electric goods company Allgemeine Elektricitäts-Gesellschaft (AEG), but also advertised an exhibition and competition organized by the Siemens Photo Club. ${ }^{39}$ As early as November 1935, one of the most important fora for "ambitious" amateur photographers, the magazine Photofreund - Halbmonatsschrift für Freunde der Photographie (Photo Friend: Semimonthly for Friends of Photography), announced the founding of a "photo group" at the Accumulatorenfabrik Hagen (Hagen Battery Factory) in Westphalia. The magazine noted that "the factory management's great interest in the activities of their employees can be seen in how they provided the photo group with an excellent workroom in which about twenty men (sic) could work together." 40

Even in the midst of World War II, another magazine, Photo-Illustrierte, announced the founding of workplace photo groups under the Reichsverband Deutscher Amateur-Fotografen (Reich Association of German Amateur Photographers, or RDAF), which had been established by the Reich Ministry of Public Education and Propaganda in 1933. ${ }^{41}$ Photo-Illustrierte mentioned a number of new photo groups in 1941, including a Fotogemeinschaft (photography collective) at the Berlin plant of Zeiss Ikon, the famous camera manufacturer; several Foto-Arbeitsgemeinschaften (photography workgroups) at various banks in Berlin and Vienna; a Fotosektion (photography department) at the Deutscher Ring insurance company in Vienna; and the Lichtbildfreunde (photo picture friends) at the Hochtief construction company in Essen. ${ }^{42}$ The existence of such groups suggests that it was not just the KdF courses mentioned so often in the scholarly literature that played a role imparting technological knowledge and competencies on aesthetic questions: the cohesion of amateur photographers in the factorieswhich was encouraged and supported by management - was in this context also significant during the Third Reich. The extent to which the working world played a role in the activities of the factory photo groups (as well as other amateur associations more generally) with respect to subject matter is

\footnotetext{
${ }^{37}$ J.B.R. [J.B. Ring], “Kraft durch Freude' auch im neuen Jahr schöpferisch. KDF-Foto-Kurse für Anfänger,” in Arbeitertum 5, no. 21 (1935-36): 28. On the KdF, see Shelley Baranowski, Strength through Joy: Consumerism and Mass Tourism in the Third Reich (Cambridge: Cambridge University Press, 2004).

${ }^{38}$ See Carl Seitz, “Gründet Werksphotogruppen,” in Photographie für Alle. Zeitschrift für alle Zweige der Photographie 33, no. 2 (Jan. 15, 1937): 28. Emphasis in original.

${ }^{39}$ See the announcements "Anschriftenänderung [der AEG.-Photo-Arbeitsgemeinschaft, Berlin]," and "Ausstellung und Wettbewerb des Photovereins 'Siemens' e.V.," in Photographie für Alle. Zeitschrift für alle Zweige der Photographie 33, no. 21 (Nov. 1, 1937): 346. By the mid-1920s, Siemens had already become one of the world's top five electric goods companies.

${ }^{40}$ See the classifieds section "Photogruppe in der Accumulatorenfabrik Hagen i. W.," in Photofreund. Halbmonatsschrift für Freunde der Photographie 15, no. 21 (Nov. 5, 1935): 418.

${ }^{41}$ See Sachsse, Die Erziehung zum Wegsehen, 120-22, 297-301.

${ }^{42}$ See "Mitteilungen. Neue Fotogruppen im RDAF," in Photo-Illustrierte 6, no. 2 (Feb. 1941): unpag. [6]; also see “Mitteilungen. Neue Fotogruppen im RDAF," in Photo-Illustrierte 6, no. 3 (March 1941): unpag. [6].
} 
unclear. Yet, there is no doubt about the motivational effect of those groups on blue- and whitecollar workers - for instance, in making it possible to exhibit their photographs.

\section{The Visual Production of Memory}

All the photos discussed in this article served to create and shape memory, but there are great differences in the way they did so, both in terms of their form and function. The company photos of assembly-line work at MAN created a kind of in-house memory of one particular stage in the production process, and thus constitute a visual document of the means of production-in both human and mechanical terms. The workers in these pictures seem anonymous and interchangeable, which may also be why such photos largely disappeared from public view in Germany after the controversy and debate in the 1930s about the effects of industrial rationalization and assembly-line processes on factory workers. This observation also points to a difficulty faced by propaganda experts who tried hard to conceal the internal contradictions of Nazi ideology toward the working masses, often referred to as the Arbeitsheer (army of workers) or Soldaten der Arbeit (soldiers of labor). The key challenge for those who, as cameramen or photographers, had to find ways of visualizing Hitler's or Ley's attempts to valorize "the worker" was to put a face on an anonymous crowd, and to avoid subjects like those unnamed, interchangeable workers engaged in assembly-line production.

Alfred Tritschler's worker portraits, by contrast, utilize the visual strategy of individualization. As we see in Figure 8, he gives an individual face to a larger workforce by staging a specific task or activity. The "corporate collective" is thus made up of many single images, and each member of the workforce could find diverse opportunities for identification with the persons and activites on display in these photographic representations. Conversely, unaffiliated spectators can assemble the individual portraits into an idealized image of worker virtues and company productivity. Tritschler's photos are thus a great deal more than mere "documentation." Taken together, his portraits convey much subtler messages than the ones suggested by the SWA press release publicizing the commemorative volume, which simply states that the reader is

taken on a tour of every department with the help of outstanding close-ups by the widely renowned photographic artist... of the Dr. Paul Wolff \& Tritschler agency. Here we can see the emergence of our wares from raw materials to finished product, and thereby appreciate how much diligence and skill was required for the successful achievement of this goal through the combined efforts of management and workforce. ${ }^{43}$

For an astute industrial photographer like Tritschler, the main priority was to satisfy the client. He knew not only how to stage symbolically charged gestures and poses effectively, but also that pictorial messages - the loyalty of factory and office workers, the company's commitment to social welfare and largesse, as well as the ideals of Betriebsgemeinschaft (company collectivity) — were best conveyed, even in the National Socialist state, with a more human touch. He did not need to invent a new visual language to achieve this. In his depiction of "types" rather than individuals, Tritschler's pars-pro-toto photographic representations were generally compatible with the ideological emphasis of Nazi propaganda on highlighting the value of "productive hands." Tritschler's photos thus offered a sort of counterpoint to earlier representations of assembly-line work, which tended to "devalue" the worker to the point where he or she almost "disappeared." Historians such as Timothy Mason have described the Nazi regime's methods of control, especially with regard to the labor force, as a strategic mix of "fear, reward, discipline, and order." ${ }^{44}$ Tritschler's photography—as exemplified

\footnotetext{
${ }^{43}$ See the press documents folder in StadtAA, SWA, company files, 189,7.

${ }^{44}$ Mason correctly describes four parallel control strategies of the Nazi regime: repression, neutralization of potential resistance, concessions in cases of discontent and unrest, and integration. But, if one includes the medium of photography in the
} 
by the imagery in Figure 13 - promotes a similar sense of "belonging" by illustrating and emotionalizing the rewards of diligence, loyalty, and conformity. But beyond such examples from prominent commercial and industrial photographers, photography under the Nazi regime proved, in general, to be highly suitable for fostering a double "integration" of workers: not only on the company level (in the sense of Betriebsemeinschaft), but also on the broader (and clearly politically assimilative) ideological level of the National Socialist state. This was demonstrated, for example, by the explicit incorporation (or "em-body-ment") of Nazi ideology in the memento page from the "Company Sports Rally" in Essen seen in Figure 5.

Similar to the photos taken by Tritschler on the occasion of the SWA company anniversary in Augsburg, H. K.'s photo also creates warm or fond memories - in this case of a workplace project for "community-building" and "improvement." The resulting feeling of community goes beyond a simple acknowledgement of participation, i.e., that the workers "also took part." Instead, this image delivers a much larger message: that they also achieved something that was good and beneficial. The nostalgic feelings evoked by this photo may have increased with the passage of time, but the positive emotional resonance of "officially" organized communitybuilding events (such as the "Sports Rally" in Figure 5) would have likely already been present at the moment. One can assume in this case that the photo stayed in H. K.'s private collection for decades. But it is impossible to say how it was used before the spring of 1982, when he finally mailed it to his former employer in the hope that it might be useful for documentation or publicity - in a company newsletter, for example. The photo then acted as a catalyst for his personal reminiscences, as well as for a "politics of memory" that was not only subjectively colored, but distinctly rose-colored. This is evident in another sentence in H. K.'s 1982 letter, one that clearly echoed an original Nazi source: "In 1935, a call promoting the Beauty of Labor was heard throughout German industry." 45

\section{Conclusion}

In the Nazi-period photographs presented in this article, one can identify two distinct strategies of visual mobilization: the illusion of "total inclusion," on the one hand, which extolled the "fulfillment of duty" through participation; visual self-mobilization, on the other, i.e., not only the mobilization of historical actors who owned a camera and used it, but also the mobilization of actors in front of the camera, sometimes as a direct result of its presence. ${ }^{46}$

When compared to corresponding visual documents from Imperial Germany and the Weimar Republic, the first of these two kinds of mobilization was only partially new and specific to National Socialism. The visual representations of a national "fulfillment of duty" seen in Figure 5, along with the accompanying slogan, do not then suggest a real break with the "nationalist" rhetoric of the pre-Nazi era. ${ }^{47}$ There is nevertheless a new quality in the manifold adaptations of genuinely National Socialist community-building opportunities, as seen in such visual

analysis, it was the symbolically loaded opportunities for integration (and its "em-body-ments") that proved to be a more longlasting topos, and one that was frequently used at the time - also in visual terms. See Timothy Mason, "Die Bändigung der Arbeiterklasse im nationalsozialistischen Deutschland. Eine Einleitung," in Angst, Belohnung, Zucht und Ordnung. Herrschaftsmechanismen im Nationalsozialismus, ed. Carola Sachse et al., (Opladen: Westdeutscher Verlag, 1982), 18, 34.

${ }^{45}$ See the document cited in note 33. According to Nazi sloganeering, the Beauty of Labor campaign strove-in the words of Robert Ley in 1936 - to give back to German workers "a sense of the worth and importance of their work." Quoted in Rabinbach, “Ästhetik der Produktion," 58.

${ }^{46}$ On amateur photographers in Nazi Germany, see Timm Starl, Knipser. Die Bildgeschichte der privaten Fotografie in Deutschland und Österreich von 1880 bis 1980 (Munich: Koehler \& Amelang, 1995), 99-110.

${ }^{47}$ On nationalist attitudes in the photography from World War I, see, e.g., Gerhard Paul, Bilder des Krieges-Krieg der Bilder. Die Visualisierung des modernen Krieges (Paderborn: Ferdinand Schöningh and Wilhelm Fink, 2004), 137-44, 153-71; Anton Holzer, Die andere Front. Fotografie und Propaganda im Ersten Weltkrieg, 2nd ed. (Darmstadt: Primus, 2007). 
documents produced by professional photographers, as well as by "normal Volksgenossen." 48 The four photos affixed to the page titled "Company Sports Rally 1942” (Betriebs-Sportappell 1942) clearly demonstrate this: they not only symbolize the general idea of taking part, but also suggest a high rate of participation. There are, after all, no spectators or passive consumers in these photos: the sole figures are actors in a collective context.

The consistent motif of the group "in movement," and the symbolic "institutionalization" of community through DAF training costumes, provide the mobilizing elements on a pictorial level. The inscription itself-"This is how every one of us does his duty" - accentuates these elements, expressing both a motivational exhortation and a successful outcome, while bestowing an ideological tinge to the sports activities being depicted: "keeping the body healthy" equals "service that honors the German people." " Compared to the pre-Nazi period, there was also increased encouragement for amateur photographers to shoot (and potentially publicize) images from the world of "German labor" and "German productivity." For example, the magazine Foto-Beobachter (Photo Observer) invited its readers in the spring of 1936 to "send in photos giving a strong impression of productive Germany, of workers of the brow and fist, from city and countryside." 50

Another important aspect that epitomizes the memory-shaping function of photography is the "afterlife," or long-term potency, of such images. The photo that H. K. preserved for decades demonstrates this, primarily in the retrospective inscription on the back, which reflects the unbroken, positive reverberation of a (workplace) community experience animated by a National Socialist worldview. H. K.'s photo has no significance at all for detached (and especially modern-day) viewers, but, for the participant himself, it is a concrete representation of his own earlier achievements in promoting "development" and "beautification." This photo is more than just a "souvenir," however: because of the retrospective assignment of meaning and significance, it has also become a pictorial symbol, at least for the individual who participated in the past event and reminisced about it in later days. H. K.'s case represents an individual attempt by a historical actor to inscribe his own biography into a highly subjective version of history. It is an act of forming and/or stabilizing identity, achieved through a positively-spun narrative of communal "achievement" and communal experience - a narrative that transcends both this individual and the caesura of 1945.

Walter Benjamin's well-known dictum-that "history breaks down into images, not into stories"-may still hold true in general. But when it comes to individual reminiscences, examples such as H. K.'s photo and inscription highlight the central role that photographic images played in generating and shaping narratives or "stories"-be they of individual experiences, collective events, or one's own life history_-as well as their (usually retrospective) placement or contextualization within larger historical frameworks. ${ }^{51}$ One can hardly overstate the value of photographs like that of H. K. as a fundamental source for historians investigating the production and shaping of memory, the establishment of purpose and identity, the construction of "participation" and "meaning," and thus - last but not least - the significant role that photography assumed in community-building processes.

Humboldt University, Berlin

\footnotetext{
${ }^{48}$ There has been little historical investigation of the role played by the photographic practices of amateurs in actively helping to shape community-building processes and the ways in which these may have become ideologically "charged" during the Nazi period. See, e.g., the examples discussed in Starl, Knipser; Sachsse, Erziehung.

${ }^{49}$ The lower two photos depicting orderly ranks of women as they jog or march, with some singing songs or reciting slogans, seem particularly in tune with the inscription's spirit.

${ }^{50}$ See "Stirn und Faust: Neuer Wettbewerb des Foto-Beobachters," in Foto-Beobachter 6, vol. 5 (May 1936): 145.

${ }^{51}$ Walter Benjamin, The Arcades Project, trans. Howard Eiland and Kevin McLaughlin (Cambridge, MA: Belknap Press, 1999), 479.
} 